\title{
URGENSI UNDANG-UNDANG PERLINDUNGAN TERHADAP SAKSI PELAPOR TINDAK PIDANA KORUPSI
}

\author{
Oleh \\ Enik Isnaini \\ Dosen Fakultas Hukum Universitas Islam Lamongan
}

\begin{abstract}
ABSTRAK
Tidak dapat lagi kita menutup mata bahwa saksi adalah, salah satu instrumen penting dalam terungkapnya suatu tabir kejahatan, Dalam sebuah proses peradilan pidana, saksi adalah salah satu kunci untuk memperoleh kebenaran materiil. Dasar hukumnya adalah pasal $184-185$ Kitab Undang-undang Hukum Acara Pidana (KUHAP)-UU No. 8 tahun 1981 yang secara tegas mengambarkan hal tersebut. Pasal 184 menempatkan keterangan saksi di urutan pertama di atas alat bukti lain berupa keterangan ahli, surat, petunjuk, dan keterangan terdakwa, Saksi termasuk pelapor sering mengalami ancaman atau tuntutan hukum atas kesaksian atau laporan yang diberikannya. Tidak sedikit pula saksi yang menjadi tersangka bahkan terpidana. Ketidakmauan saksi untuk memberikan keterangan di pengadilan, biasanya terjadi untuk kasus-kasus antara lain seperti kekerasan terhadap perempuan, kekerasan dalam Rumah Tangga, korupsi dan pelanggaran HAM berat. Selain daripada itu, saksi juga harus dibebaskan dari perasaan takut dan khawatir akan dampak dari keterangan yang diberikannya. Seseorang mungkin saja menolak untuk menjadi saksi, atau, kalau pun dia dipaksa, kesaksiannya adalah bohong karena, barangkali ia tidak mau mempertaruhkan kedudukannya, nyawanya atau nyawa keluarganya gara-gara keterangannya yang memberatkan terdakwa.
\end{abstract}

Kata kunci : Saksi pelapor, Tindak Pidana, Korupsi.

\section{PENDAHULUAN1.}

\section{Latar belakang}

Tidak dapat lagi kita menutup mata bahwa saksi adalah, salah satu instrumen penting dalam terungkapnya suatu tabir kejahatan. Seperti yang diatur dalam pasal 1 ayat (26) UU Nomor 8 tahun 1981 yang disebut sebagai berikut :

"Saksi adalah orang yang dapat memberikan keterangan guna kepentingan penyidikan, penuntutan dan peradilan tentang suatu perkara pidana yang ia dengar sendiri, ia lihat sendiri dan ia alami sendiri."

Berdasarkan definisi tersebut, maka saksi diharapkan dapat menjelaskan rangkaian kejadian yang berkaitan dengan sebuah peristiwa yang menjadi obyek pemeriksaaan di muka persidangan. Saksi, bersama dengan alat bukti yang lainnya, akan membantu hakim dalam rangka

menjatuhkan putusan yang adil dan obyektif berdasarkan fakta-fakta hukum yang telah diberikan.Dalam sebuah proses peradilan pidana, saksi adalah salah satu kunci untuk memperoleh kebenaran materiil. Dasar hukumnya adalah pasal 184 - 185 Kitab Undang-undang Hukum Acara Pidana (KUHAP)-UU No. 8 tahun 1981 yang secara tegas mengambarkan hal tersebut. Pasal 184 menempatkan keterangan saksi di urutan pertama di atas alat bukti lain berupa keterangan ahli, surat, petunjuk, dan keterangan terdakwa. Pasal 185 (2) menyatakan :

"Keterangan seorang saksi saja tidak cukup untuk membuktikan bahwa terdakwa bersalah terhadap perbuatan yang didakwakan kepadanya." 
Ayat (3) dari pasal yang sama berbunyi:

"Ketentuan sebagaimana

dimaksud dalam ayat (2) tidak

berlaku apabila disertai dengan

alat bukti yang sah lainnya."

Hal ini dapat diartikan bahwa keterangan lebih dari 1 (satu) orang saksi saja bila disertai alat bukti lainnya, dapat dianggap cukup untuk membuktikan apakah seorang terdakwa bersalah atau tidak.

Pada saat memberikan keterangannya, saksi harus dapat memberikan keterangan yang sebenarbenarnya dan bukan merupakan rekayasa. Untuk itulah, saksi perlu merasa aman dan bebas saat diperiksa keterangannya di muka persidangan, ia tidak boleh ragu-ragu menjelaskan peristiwa yang sebenarnya, walaupun mungkin keterangannya itu akan memberatkan terdakwa. Maka pasal 173 UU Nomor 8 tahun 1981 memberikan kewenangan kepada Majelis Hakim untuk memungkinkan seorang saksi didengar keterangannya tanpa kehadiran terdakwa.

"Hakim ketua sidang dapat mendengar keterangan saksi mengenai hal tertentu tanpa hadirnya terdakwa, untuk itu ia minta terdakwa keluar dari ruang sidang akan tetapi sesudah itu pemeriksaan perkara tidak boleh diteruskan sebelum kepada terdakwa diberitahukan semua hal pada waktu ia tidak hadir".

Saksi termasuk pelapor sering mengalami ancaman atau tuntutan hukum atas kesaksian atau laporan yang diberikannya. Tidak sedikit pula saksi yang menjadi tersangka bahkan terpidana. Ketidakmauan saksi untuk memberikan keterangan di pengadilan, biasanya terjadi untuk kasus-kasus antara lain seperti kekerasan terhadap perempuan, kekerasan dalam Rumah Tangga, korupsi dan pelanggaran HAM berat. Selain daripada itu, saksi juga harus dibebaskan dari perasaan takut dan khawatir akan dampak dari keterangan yang diberikannya. Seseorang mungkin saja menolak untuk menjadi saksi, atau, kalau pun dia dipaksa, kesaksiannya adalah bohong karena, barangkali ia tidak mau mempertaruhkan kedudukannya, nyawanya atau nyawa keluarganya gara-gara keterangannya yang memberatkan terdakwa.

Di sisi lain, seseorang menolak memberikan keterangan karena mengalami trauma yang hebat akibat peristiwa pidana sehingga tidak memiliki kemampuan untuk menceritakan ulang peristiwa yang dialaminya itu. Tidak sedikit kasus yang tidak dapat dibawa ke muka persidangan atau pun terhenti di tengah jalan karena persoalan yang satu ini. Kasus-kasus seperti kejahatan korupsi atau kejahatan narkotika yang melibatkan sebuah sindikat, menjadi contoh kasus yang seringkali tidak dapat diproses karena tidak ada saksi yang mau dan berani memberikan keterangan yang sebenarnya.

Maka yang terjadi kemudian adalah bukan saja gagalnya sebuah tuntutan untuk melakukan proses peradilan yang bersih, jujur, dan berwibawa untuk memenuhi rasa keadilan masyarakat, tetapi juga pelanggaran hak-hak asasi individual 
yang terkait dalam kasus tersebut. Dengan hal tersebut menyebabkan ketersediaan mekanisme perlindungan saksi amat penting untuk menjamin diperolehnya kebenaran materil sekaligus untuk memenuhi rasa keadilan bagi semua, termasuk bagi saksi yang terkait.

Mekanisme perlindungan saksi dalam proses peradilan misalnya, kasus-kasus kejahatan HAM juga diakui dunia sebagai sebuah keniscayaan. Mahkamah Pidana Adhoc untuk bekas negara Yugoslavia dan untuk Rwanda secara eksplisit menyebutkan hal tersebut pada statuta dan aturan teknis prosedur pengadilan. Hal yang sama juga termaktub secara eksplisit di statuta Mahkamah Pidana Internasional yang mulai beroperasi tanggal 1 Juli 2002. Pasal 6 huruf (d) Deklarasi PBB tentang Prinsip-prinsip Dasar Keadilan bagi Korban Kejahatan dan Penyalahgunaan Kekuasaan (UN Declaration of Basic Principles of Justice for Victims of Crime and Abuse of Power) menyatakan bahwa proses peradilan harus :

\footnotetext{
"mengambil langkah-langkah untuk meminimalisir ketidaknyamanan korban, melindungi privasi mereka, manakala dibutuhkan, dan memastikan keselamatan mereka dan juga anggota keluarga saksisaksi mereka dari intimidasi dan tindakan balas dendam, (measures to minimise inconvenience to victims, protect their privacy, when necessary, and ensure their safety, as well as that of their families and witnessess on their
}

behalf, from intimidation and retaliation)."

Argumen utama perlunya diadakan lembaga perlindungan saksi adalah karena dalam situasi transisi, terdakwa atau tersangka kasus korrpsi dan para pendukungnya masih demikian banyak dan berkuasa, maka setiap saksi yang akan memberikan keterangan memberatkan adalah dianggap sebagai "musuh". Mekanisme perlindungan saksi dan korban yang jelas dan terpercaya dapat membantu saksi yang selama ini bungkam karena takut dapat merasa aman untuk berbicara membeberkan kejahatan korupsi yang diketahuinya.

Untuk itulah kenapa perlunya produk hukum yang didalamnya mengamanatkan untuk dibangun suatu lembaga khusus yang bergerak di bidang perlindungan saksi dan korban. Lembaga perlindungan saksi sebaiknya dibangun berdasarkan sisi perspektif saksi dan korban dengan menjadikan faktor keamanan sebagai prioritas utama. Saksi perlu diberi rasa kepercayaan bahwa pengadilan yang akan dihadapinya adalah sebuah pengadilan yang berwibawa dan dapat dipercaya; mampu melindungi dirinya sebelum, pada saat, dan setelah memberikan kesaksian. Dalam konteks berpikir seperti ini, maka yang dibutuhkan bukan hanya pemberian fasilitas keamanan fisik saja, tetapi juga jasa konsultasi psikologi. Hal ini selain dapat membantu saksi dan korban siap untuk memberikan keterangan, juga dapat menjadi alat bantu memulihkan saksi sebagai awal 
persiapan untuk kembali memulai hidupnya.

Di Indonesia, hal perlindungan saksi nampaknya kurang cukup mendapat perhatian serius. Namun sudah ada produk hukum yang mengakomodir perlindungan saksi terutama dalam kasus pelanggaran HAM berat. Undang-Undang Pengadilan HAM UU Nomor 26 tahun 2000 secara teoritis juga mengakui pentingnya aspek perlindungan saksi dan korban dalam proses pemeriksaan pengadilan kasus-kasus kejahatan pelanggaran HAM berat.

Pasal 34 dari UU ini menyatakan bahwa aparat penegak hukum dan aparat keamanan diharuskan menyediakan perlindungan bagi saksi dan korban. Kemudian sebagai tindak lanjut dari UU tersebut Tanggal 13 Maret 2002 Pemerintah mengeluarkan PP Nomor 2 tahun 2002 tentang Tata Cara Perlindungan terhadap korban dan saksi dalam Pelanggaran Hak Asasi Manusia yang Berat.

Buruknya kualitas perlindungan saksi dan korban, juga bersumber dari buruknya kualitas pemahaman Majelis Hakim dan Jaksa Penuntut Umum tentang peran sentral jabatannya untuk membantu mencari kebenaran materil. Dalam banyak kesempatan, Majelis Hakim dan Jaksa Penuntut Umum membiarkan saksi-saksi diintimidasi oleh penasihat hukum terdakwa melalui berbagai pertanyaan yang menyudutkan dan bukan dimaksudkan untuk tujuan mencari fakta dari peristiwa yang didakwakan.

Makna perlindungan saksi tidak hanya diperlukan pada saat sebelum dan sesudah saksi memberikan keterangannya di muka persidangan. Penting juga untuk memberikan rasa aman dan percaya diri pada saksi dan korban bahwa persidanganlah yang membutuhkan keterangannya untuk membantu Pengadilan memperoleh kebenaran yang sebenar-benarnya, bukannya dimaksudkan untuk menghukum dan memberikan sanksi pada saksi karena memutuskan untuk memberikan keterangannya sebagai saksi.

\subsection{Perumusan Masalah}

Sesuai dengan judul dan latar belakang masalah di atas, maka penulis mengetengahkan dua permasalahan yaitu :

1. Bagaimana bentuk perlindungan saksi pelapor dalam tindak pidana korupsi ?

2. Kendala-kendala apa sajakah yang dihadapi dalam upaya perlindungan hukum terhadap saksi pelapor tindak pidana korupsi ?

\subsection{Tujuan Penelitian}

1. Untuk mengetahui bagaimana bentuk perlindungan hukum terhadap saksi pelapor tindak pidana korupsi sebagai bagian integral dari komitmen pemerintah terhadap pemberantasan korupsi di Indonesia.

2. Untuk mengetahui kendala-kendala apa saja yang dihadapi dalam upaya melindungi saksi

\section{METODE PENELITIAN}

Tipe penelitian hukum yang dilakukan adalah yuridis normatif 
(hukum normatif). Metode penelitian hukum normatif adalah suatu prosedur penelitian ilmiah untuk menemukan kebenaran berdasarkan logika keilmuan hukum dari sisi normatifnya. ${ }^{1}$

Oleh karena tipe penelitian yang digunakan adalah tipe penelitian yuridis normatif, maka pendekatan yang digunakan adalah pendekatan perundangundangan (statute approach). Pendekatan tersebut melakukan pengkajian peraturan perundang-undangan yang berhubungan dengan pokok permasalahan. Selain itu juga digunakan pendekatan konsep (Conseptual approach). Pendekatan konsep ini digunakan dalam rangka untuk melihat konsep-konsep perlindungan hukum terhadap saksi pelapor dalam tindak pidana korupsi

\section{HASIL DAN PEMBAHASAN}

\subsection{Pengertian saksi}

Pengertian saksi sendiri diatur dalam Kitab Undang-Undang Hukum Acara Pidana (KUHAP) dalam pasal 1 ayat (26) yakni :

1. "Orang yang dapat memberikan keterangan guna kepentingan penyidikan, penuntuan dan peradilan tentang suatu perkara pidana yang ia dengar sendiri, ia lihat sendiri dan ia alami sendiri"

2. Pengertian saksi Rancangan Undang-undang Perlindungan Saksi dan Korban ini menggunakan konsep tentang pengertian saksi yang diatur dalam KUHAP. Saksi dinyatakan sebagai orang yang hendak

1 Johnny Ibrahim, Teori \& Metode Penelitian Hukum Normatif, Banyumedia Publishing, Malang 2006, h..57 memberikan keterangan guna kepentingan penyelidikan, penyidikan, penuntutan, dan peradilan tentang suatu perkara pidana yang ia dengar sendiri, ia lihat sendiri dan atau ia alami sendiri. Perbedaannya dengan rumusan dalam KUHAP ini adalah bahwa peran saksi mulai dari tahap penyelidikan. Definisi ini bila kita kaji pembuat UU coba menjangkau pada saksi pelapor yang seringkali terdapat dalam kasus-kasus korupsi. Tentang pelapor sendiri sebenarnya UU Nomor 31 tahun 1999 telah mengatur di dalam pasal 31 yang menyebutkan bahwa pelapor tidak dapat diajukan dalam sidang pengadilan melainkan harus dilindungi identitas dan alamatnya.

3. Saksi dalam Rumusan RUU perlindungan saksi ini dinyatakan sebagai saksi yang akan memberikan keterangan untuk mendukung proses penyelesaian perkara pidana. Dalam pengertiannya saksi terpisah dari pihak-pihak yang berhubungan dengan saksi. Pembuat UU ini lebih memilah-milah antara pengertian saksi dengan keluarga saksi.

4. Dalam RUU perlindungan saksi dan korban dijelaskan dalam pasal 1 ayat (6) tentang siapa saja yang dimaksud dengan keluarga saksi : "Keluarga saksi dan/atau korban adalah orang-orang yang mempunyai hubungan darah dalam garis lurus, atau mempunyai hubungan darah dalam garis 
menyamping sampai derajat ketiga, atau mempunyai hubungan perkawinan dengan saksi dan atau orang-orang yang menjadi tanggungan saksi", Perlindungan dalam artian luas seperti tercantum dalam pasal 1 ayat (6) RUU perlindungan saksi dan korban diatas mempunyai daya jangkau yang cukup luas, karena nantinya pelaksanaan perlindungan terhadap saksi bukan hanya pada saksi itu sendiri, namun pihak-pihaklain yang mempunyai kaitan dengan saksi juga mungkin saja membutuhkan perlindungan.

\subsection{Teori atau sistem pembuktian}

Di dalam lingkungan Hukum acara Pidana dikenal ada beberapa teori atau sistem pembuktian ${ }^{2}$ sebagai berikut :

1. Sistem Pembuktian Menurut Keyakinan atau Conviction Time Untuk menentukan salah tidaknya terdakwa, semata-mata hanya ditentukan leh keyakinan hakim saja. Meskipun terdakwa dengan alat-alat bukti yang ada terbukti melakukan tindak pidana namun pembuktian tersebut dapat dikesampingkan oleh keyakinan hakim. Demikian pula sebaliknya, meskipun terdakwa berdasarkan alat-alat bukti yang ada tidak terbukti melakukan tindak pidana dapat saja dinyatakan terbukti bersalah semata-mata karena berdasarkan keyakinan hakim.

M. Yahya Harahap, Pembahasan Permasalahan dan Penerapan KUHAP Jilid II, Cetakan III, Pustaka Kartini, Jakarta, 1993, hal. 797-800
2. Sistem Pembuktian menurut keyakinan berdasarkan alasan yang jelas dan dapat diterima atau Conviction Raisonee. Untuk menentukan bersalah tidaknya terdakwa, keyakinan hakim harus berdasarkan alasan-alasan yang jelas dan dapat diterima, tidak semata-mata keyakinan hakim saja.

3. Sistem Pembuktian secara positif menurut Undang-undang. Untuk menentukan terdakwa telah melakukan tindak pidana, sematamata tergantung dari alat-alat bukti yang sah dengan syaratsyarat yang telah ditentukan oleh peraturan perundang-undangan. Meskipun terdakwa berdasarkan keyakinan hakim melakukan tindak pidana, jika berdasarkan alat bukti yang ada terdakwa tidak melakukan tindak pidana hakim harus tetap memutus terdakwa tidak melakukan tindak pidana.

Sistem Pembuktian Negatif Menurut Undang-undang (Negative Wettelijk) Untuk menentukan bersalah tidaknya terdakwa telah melakukan tindak pidana, tergantung dari keyakinan hakim yang didasarkan pada alatalat bukti dengansyarat-syarat yang telah ditentukan oleh peraturan perundang-undangan. Hakim baru menyatakan terdakwa telah terbukti melakukan tindak pidana jika hakim mempunyai keyakinan yang didasarkan alatalat bukti dengan syarat-syarat yang ditentukan oleh peraturan perundang-undangan. 


\subsection{Kekuatan pembuktian}

Kekuatan pembuktian keterangan saksi dikorelasikan pada penjelasan pasal 1 ayat (27) dengan pasal 116 ayat (2) UU Nomor 8 tahun 1981 :

a. Memberikan keterangan yang sebenarnya sehubungan dengan tindak pidana yang sedang diperiksa. Kata kunci pemeriksaan saksi adalah tindak pidana yang sedang coba diungkap oleh penyidik.

b. Keterangan saksi yang digunakan untuk kepentingan pemeriksaan Patokannya menunjuk pada pasal 1 ayat (27) dan pasal 185 ayat (5). Seperti yang ditegaskan dalam pasal 185 ayat (5) yakni "pendapat" dan "rekaan" yang diperoleh dari hasil pemikiran atau kesimpulan bukan termasuk dalam keterangan saksi. Dengan penegasan dalam pasal ini pemeriksaan dapat diarahkan oleh penyidik pada pasal 1 ayat (27) unsur-unsurnya, yaitu :

"Yang ia dengar sendiri" berarti saksi mendengar langsung dengan indera pendengarannya bukan hasil pendengaran dari orang lain. Dengan kata iain peristiwa itu harus didengar secara pribadi oleh saksi yang bersangkutan.

"yang ia lihat sendiri", Berarti pada waktu kejadian ataupun rentetan kejadian peristiwa pidana sungguh-sungguh dilihat oleh mata kepala sendiri. Tentu kebanyakan saksi tidak mungkin dapat melihat secara utuh kronologis atau rentetan peristiwa mulai dari awal sampai akhir. Meski begitu tidak mengurangi arti bahwa saksi yang dipanggil dan diperiksa sekurang-kurangnya melihat dengan mata kepala sendiri sebagian dari peristiwa pidana yang terjadi”.

"Atau yang dialami sendiri oleh saksi", saksi seperti ini adalah juga korban atau orang yang dirugikan dari peristiwa tersebut".

"Selain itu baik pendengaran sendiri maupun pengalaman sendiri dan saksi, harus didukung oleh alasan "pengetahuannya",

Jumlah saksi diatur dalam pasal 185 ayat (2) dengan asasnya "Unus Testis Nullus Testis", keterangan satu saksi bukanlah kesaksian, artinya keterangan dari seorang saksi saja, tidak cukup untuk membuktikan kesalahan terdakwa, jadi untuk kepentingan pembuktian penyidik minimal harus menyiapkan 2 (dua) orang saksi. $^{3}$

Korupsi mengakibatkan mertabat bangsa menjadi rendah, kehidupan masyarakat menjadi tidak tenteram kerena masyarakat harus menanggung pajak yang tinggi sebagai akibat dari korupsi yang dilakukan oleh para pejabat pemerintah termasuk pinjaman IMF/CGI/World Bank. Korupsi para pejabat mengakibatkan defisif APBN. Defisit APBN tersebut harus ditutup, salah satu dengan kenaikan pajak, menaikkan harga BBM, harga PLN, dan lain-lain. Tetapi sampai saat ini belum terdapat hukum yang memadai untuk memberantas korupsi sehingga tidak mungkin dicapai ketertiban umum (tidak

M. Yahya Harahap, SH., Pembahasan Permasalahan dan Penerapan KUHAP, Sinar Grafika, Jakrta, 2000, hal. 140-142 
terdapat Law and Order) tanpa upaya luar biasa berupa terobosan-terobosan terhadap korupsi. Sampai sedemikian parahnya korupsi di Indonesia, sehingga dari sudut pandang pihak asing, contohnya seperti yang dikemukan oleh Gary Goodpaster:

"in Reflections on Corruption in Indonesia that there is a common saying that Indonesia government employees are paid a salary to show up, not to work."

Lemahnya respons yuridis di negara kita dalam upaya penyelesaian berbagai kasus korupsi terutama yang melibatkan pejabat-pejabat ataupun orang-orang penting yang identik dengan kekuasaan disebabkan salah satunya oleh tidak adanya mekanisme untuk melindungi para saksi pelapor tindak pidana korupsi, maupun berbagai kasus lainnya. Peran saksi pada keberhasilan suatu proses peradilan pidana sangat besar dan strategis, tidak sedikit kasus korupsi yang menyangkut pejabat negara yang kandas di tengah jalan disebabkan oleh karena ketiadaan saksi yang dapat mendukung peran aparat penegak hukum.

Oleh karenanya keberadaan saksi merupakan suatu unsur yang sangat menentukan dalam suatu proses peradilan pidana. Peran saksi selama ini sangat jauh dari perhatian masyarakat dan penegak hukum, banyaknya kasus-kasus yang tidak terungkap dan tidak terselesaikan disebabkan keengganan saksi untuk memberikan keterangan karena mendapatkan ancaman dari pihakpihak tertentu, Lemahnya sistem perlindungan saksi semakin tampak ketika menyangkut pembongkaran kasus korupsi atau kejahatan yang dilakukan secara terorganisasi (organized crime).
Contohnya adalah pada kasus Bank Bali yang sangat terkesan ditutupi-tutupi karena banyaknya pejabat yang terlibat."

Keadaan semacam ini tidak bisa dibiarkan berlarut-larut dalam era transisi ini, karena waktu yang kita miliki sangat singkat untuk menyelamatkan negara dari kebangkrutan nasional akibat ulah para koruptor. Bagaimana masyarakat tidak memilih diam saja kalau melihat sudah banyak saksi pelapor yang memiliki idealisme dan kepekaan yang tinggi malah berstatus sebagai tersangka pencemaran nama baik karena dilaporkan balik oleh orang yang semula dilaporkannya sebagai pelaku tindak pidana korupsi. Sebagian besar kasus yang dilaporkan tersebut melibatkan nama-nama yang terkenal, memiliki kekuatan politik maupun pendanaan yang kuat.

Indonesian Corruption Watch (ICW) dalam data yang dimilikinya mencatat sejumlah kasus saksi pelapor yang di meja hijaukan sebagai tersangka pencemaran nama baik. Sementara itu, kasus utama yang dilaporkan itu sendiri sama sekali tidak diproses. Catatan yang dibuat sejak tahun 1996 itu menunjukkan 80 persen kasus yang dilaporkan terjadi di luar DKI Jakarta. Dari data tersebut, 24 kasus pelaporan korupsi berbalik mengenai para saksi menjadi kasus pencemaran nama baik. Beberapa laporan pencemaran nama baik justru melibatkan otoritas tertinggi pengadilan, yakni Mahkamah Agung.

Nasib lebih ironis dialami Muchtar Lufthi. Ia melaporkan dugaan korupsi pengadaan kapal KMP di Pulau Weh yang melibatkan Wali Kota Sabang Sofyan Harun. Kasus itu merugikan 
negara senilai Rp 8,6 miliar. Bukannya kasus itu yang ditangani polisi, Muchtar Lufthi malah dilaporkan ke Polres Sabang. Pasca pelaporan itu, Polres Sabang mengeluarkan surat penangkapan terhadap Muchtar. Sekalipun kasus itu telah dilaporkan ke Kejaksaan Agung dan Mabes Polri, namun hingga sekarang tidak jelas penanganannya. Anggota KPU Chusnul Mariyah juga pernah melaporkan pakar multimedia Roy Suryo Notodiprojo ke Polda Metro Jaya karena dianggap mencemari namanya. Pasalnya adalah sebelumnya, Roy Suryo melaporkan dugaan korupsi pengadaan teknologi informasi di KPU yang dilakukan Chusnul. Roy sempat diperiksa polisi meskipun akhirnya Chusnul juga terjerat oleh KPK sehubungan dengan kasus yang sama. ${ }^{4}$

\subsection{Pengertian Korupsi}

Secara umum, pengertian korupsi adalah perbuatan yang menyimpang dari tugas-tugas resmi sebuah jabatan negara yang merugikan kepentingan publik atau masyarakat luas untuk kepentingan atau keuntungan pribadi maupun golongan. ${ }^{5}$, selain itu pengertian korupsi juga diatur dalam UU Nomor 31 tahun 1999 jo Undang-Undang Nomor 20 Tahun 2001, pada Pasal 2 ayat (I) yang berbunyi "Tindak pidana korupsi adalah setiap orang yang secara melawan hukum melakukan perbuatan memperkaya diri sendiri atau orang lain atau suatu korporasi yang dapat merugikan keuangan negara atau perekonomian negara...".

\footnotetext{
4 Sinar Harapan, "Ketika Laporan Berbalik Tuduhan" 27 Juni 2005

5 Suharko, "Anti Korupsi, Pemberantasan Korupsi dan Penguatan Kemauan Politik" 4/Mei/2004, hal.4
}

Langkah penegak hukum akhirakhir ini perlu kita hargai, karena mereka telah mulai menampakkan prestasinya dengan lebih berani membongkar kasus dalam waktu yang relatif cepat, Telah disebutkan di depan, bahwa korupsi adalah salah satu kejahatan yang rapi dan terkoordinir sehingga sangat sulit ditembus dan diakses transparansinya oleh khalayak umum. Kerapian dan terorganisirnya kejahatan ini salah satu sebabnya adalah tindak pidana korupsi ini adalah kejahatan yang erat hubungannya dengan kekuasaan dan penguasa, Perlindungan terhadap para saksi tidak kalah pentingnya seperti perlindungan yang perlu diberikan terhadap para jaksa yang melakukan penuntutan hukum terhadap para koruptor. Sebab bila jaksa dilindungi sementara saksi tidak ada yang melindungi, tentu saja proses pemberantasan korupsi secara keseluruhan tidak akan pernah bisa maksimal. Lebih-lebih sekarang ini banyak fakta tentang merebaknya aksi-aksi intimidasi, teror dan kekerasan terhadap para saksi yang berani melawan para koruptor, kalau tidak ada perlindungan jelas negara terlihat setengah hati dalam memberantas korupsi karena para saksi yang telah banyak jasanya itu harus memikul resiko sendiri, Sejauh ini Indonesia memang baru memiliki produk perundangan-undangan untuk perlindungan saksi dalam kasus tindak pidana terorisme. Hal ini diatur dalam Peraturan Pemerintah No. 24 Tahun 2003 tentang Tata Cara Perlindungan terhadap Saksi, Penyidik, Penuntut Umum, dan Hakim dalam Perkara Tindak Pidana Terorisme. Sementara itu, untuk para saksi pelapor tindak pidana korupsi, proteksi hukum serupa belum tersedia. 
PP Nomor 2 Tahun 2002 ini adalah amanat dari Pasal 34 UU Nomor 26 Tahun 2000 yang mengatakan bahwa saksi dan korban pada kejahatan HAM berat berhak untuk mendapatkan perlindungan. Pengertian perlindungan saksi pada PP Nomor 2 Tahun 2002 tentang Tata Cara Perlindungan Terhadap Korban dan Saksi Pada Pelanggaran HAM berat Pasal 1 angka (1) PP tersebut menyebutkan :

"Perlindungan adalah suatu bentuk pelayanan yang wajib dilaksanakan oleh aparat penegak hukum atau aparat keamanan untuk memberikan rasa aman baik fisik maupun mental, kepada korban dan saksi, dari ancaman, gangguan, teror, dan kekerasan dari pihak manapun, yang diberikan pada tahap penyelidikan, penyidikan, penuntutan, dan atau pemeriksaan di sidang pengadilan"

Dalam pasal 4 PP No 2 tahun 2002 tentang Tata Cara Perlindungan Terhadap Korban dan Saksi Pada Pelanggaran HAM perlindungan meliputi:

a. Perlindungan atas keamanan pribadi korban atau saksi dari ancaman fisik dan mental;

b. Perahasiaan identitas korban atau saksi;

c. Pemberian keterangan pada saat pemeriksaan di sidang pengadilan tanpa bertatap muka dengan tersangka.

Disebutkan pada pasal 8 ayat (1) bahwa : "Segala biaya yang diperlukan untuk pelaksanaan perlindungan terhadap korban dan saksi dibebankan pada anggaran masing-masing instansi aparat penegak hukum atau aparat keamanan."

Artinya ada niatan baik, bahwa saksi itu mendapat tempat yang cukup dihargai, yakni kesaksiannya dianggap diperlukan oleh pengadilan, bukannya dia yang membutuhkan memberi kesaksian di pengadilan. Sehingga dalam dia memberikan kesaksian, keselamatan dirinya dijamin oleh adanya sistem peradilan pidana yang berwibawa. Namun yang menjadi indikator betapa setengah hatinya pemerintah dalam upaya menyelenggarakan peradilan adalah anggaran perlindungan saksi itu bukan menjadi Anggaran dan Biaya Tambahan, namun dibebankan pada anggaran instansi aparat penegak hukum atau aparat keamanan.

Seperti kita tahu, bahwa aparat penegak hukum saat ini budgetnya sudah sangat terbatas dan cenderung kurang, masih ditambah harus menanggung beban biaya perlindungan saksi dalam kejahatan tingkat tinggi.

Sedangkan dalam Peraturan Pemerintah Nomor 71 tahun 2000 tentang Tata Cara Pelaksanaan Peran Serta Masyarakat dan Pemberian Penghargaan dalam pencegahan dan pemberantasan Tindak Pidana Korupsi Pasal 2 menyebutkan bahwa:

"Setiap orang, Organisasi Masyarakat, atau Lembaga Swadaya Masyarakat berhak mencari, memperoleh dan memberikan informasi adanya dugaan telah terjadi tindak pidana korupsi serta menyampaikan saran dan pendapat kepada penegak hukum dan atau Komisi 
mengenai perkara tindak pidana korupsi".

Namun syarat sahnya sebuah laporan menurut pasal 3 ayat (1) PP ini mengatur laporan itu harus disampaikan secara tertulis dan disertai:

a. Data mengenai nama dan alamat pelapor, pimpinan Organisasi Masyarakat, atau pimpinan Lembaga Swadaya Masyarakat dengan melampirkan foto kopi kartu tanda penduduk atau identitas diri lain;

b. keterangan mengenai dugaan pelaku tindak pidana korupsi dilengkapi dengan bukti-bukti permulaan.

Sementara untuk melindungi masyarakat yang ikut berperan serta dalam mencegah Tindak Pidana Korupsi maka pasal 5 PP ini mengatur mengenai perlindungan saksi :

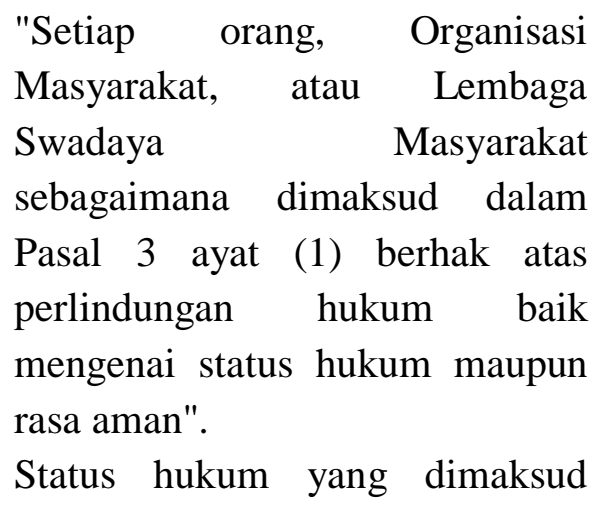
dalam pasal 5 ayat (1) tersebut mempunyai artian bahwa status seseorang pada waktu menyampaikan suatu informasi, saran, atau pendapat kepada penegak hukum atau komisi dijamin tetap, misalnya status sebagai pelapor tidak diubah menjadi sebagai tersangka.

Namun perlindungan tersebut tidak diberikan dengan klausula pada pasal 5 ayat(2) :
"Perlindungan mengenai status hukum sebagaimana dimaksud dalam ayat (1) tidak diberikan apabila dari hasil penyelidikan atau penyidikan terdapat bukti yang cukup yang memperkuat keterlibatan pelapor dalam tindak pidana korupsi yang dilaporkan".

Hal ini untuk mencegah lolosnya jeratan terhadap pelaku yang melaporkan dugaan korupsi yang diperbuatnya dengan tujuan menghilangkan jejak dan mendapat perlindungan hukum terhadap status dirinya.

Produk hukum yang paling dekat dengan upaya perlindungan yang ditujukan bagi saksi pelapor Tindak Pidana Korupsi adalah Undang-undang Nomor 30 tahun 2002 tentang Komisi Pemberantasan Korupsi (KPK) yang disebutkan dalam UU tersebut. Anggota KPK telah disumpah untuk tidak mengungkap atau melindungi nara sumber Dalam pasal 15 huruf a UU tentang KPK menyebutkan sebagai berikut:

"KPK berkewajiban memberikan perlindungan terhadap saksi atau pelapor yang menyampaikan laporan atau pun memberikan keterangan mengenai terjadinya tindak pidana korupsi. Yang dimaksud memberikan perlindungan diantaranya ialah merahasiakan identitas pelapor, memberikan jaminan keamanan bagi pelapor maupun saksi dengan meminta bantuan kepolisian, atau dalam bentuk penggantian identitas pelapor, juga melakukan evakuasi serta perlindungan hukum terhadap 
saksi maupun pelapor tindak pidana korupsi".

Selama belum ada Undangundang perlindungan saksi yang mengatur lebih-lengkap lagi mengenai tata cara dan wadah apa yang akan dibentuk guna melindungi saksi pelapor tindak pidana korupsi maka KPK harus berinisiatif membentuk unit khusus perlindungan saksi, tidak hanya sekedar merahasiakan identitas saksi atau pelapor, tapi juga harus memberi jaminan keamanan dan perlindungan bagi saksi pelapor maupun keluarganya.

maka produk hukum yang mengatur tentang pemberantasan tindak pidana korupsi seharusnya sudah disiapkan secara lengkap, seperti misalnya ketika pembuatan UU 31 tahun 1999 yang di dalamnya mengamanatkan partisipasi aktif masyarakat, logikanya pemerintah juga harus sudah menyiapkan regulasi khusus yang sederajat dengan regulasi tentang pemberantasan korupsi yang mengatur perlindungan bagi masyarakat pelapor adanya dugaan korupsi.

\section{PENUTUP}

\subsection{Kesimpulan}

Berdasarkan analisis kasus di atas, maka dapat disimpulkan beberapa hal sebagai berikut :

1. Bentuk perlindungan hukum terhadap saksi tindak pidana korupsi di Negara Indonesia adalah disesuaikan dengan Undang-undang Nomor 13 Tahun 2006 tentang Perlindungan Saksi dan Korban dimana saksi diberikan perlindungan oleh suatu lembaga yaitu Lembaga
Perlindungan Saksi dan Korban untuk dapat dipergunakan dalam proses peradilan tindak pidana korupsi itu sendiri.

2. Kendala dalam memberikan perlindungan saksi adalah kurang terjaminnya keamanan saksi sebagai konsekuensi dari belum adanya suatu bentuk regulasi yang khusus mengatur masalah perlindungan saksi. Banyaknya saksi pelapor yang diajukan oleh pihak terlapor ke pengadilan dengan tuntutan pencemaran dan Pelaku korupsi yang dekat dengan kekuasaan dan mempuyai pengaruh jelas menjadi ancaman bagi saksi apabila produk yuridis untuk melindungi status dan keberadaan saksi pelapor belum juga dibentuk.

\subsection{Saran}

Lembaga perlindungan saksi dan korban (LPSK) diharpkan sebagai satu-satunya lembaga yang dapat memberikan perlindungan terhadap saksi terutama saksi pelapor dalam pekara pidana korupsi sehingga saksi tidak terasa terancam dan bisa membuka kebenaran fakta dalam persidangan.

\section{Catatan kaki :}

(1) Johnny Ibrahim, Teori \& Metode Penelitian Hukum Normatif, Banyumedia Publishing, Malang 2006, h..57

(2) M. Yahya Harahap, Pembahasan Permasalahan dan Penerapan KUHAP Jilid II, Cetakan III, Pustaka Kartini, Jakarta, 1993, hal. 797-800 
(3) M. Yahya Harahap, SH., Pembahasan Permasalahan dan Penerapan KUHAP, Sinar Grafika, Jakrta, 2000, hal. 140-142

(4) Sinar Harapan, "Ketika Laporan Berbalik Tuduhan” 27 Juni 2005

(5) Suharko, "Anti Korupsi, Pemberantasan Korupsi dan Penguatan Kemauan Politik" 4/Mei/2004, hal.4

\section{LITERATUR :}

Bagir Manan, Sistem Peradilan Berwibawa (Suatu Pencarian), UII Press, Yogyakarta, 2005.

Baharuddin Lopa, Kejahatan Korupsi dan Penegakan Hukum, Kompas, Jakarta, 2001

Johnny Ibrahim, Teori \& Metode Penelitian Hukum Normatif, Banyumedia Publishing, Malang 2006,

Peter Mahmud Marzuki. Penelitian Hukum. Universitas Air Langga. Surabaya.

R. Wiyono, Pembahasan UU Tindak Pidana Korupsi, Sinar Grafika, Jakarta, 2005

Martiman Prodjohamidjojo, Pembahasan Hukum Acara Pidana, PT. Pradnya Paramita, Jakarta, 1988

Moeljatno, Asas-asas Hukum Pidana, Rineka Cipta, Jakarta, 2002

Luhut Pangaribuan, Hukum Acara Pidana, Djambatan, Jakarta, 2002

M. Yahya Harahap, Pembahasan Permasalahan dan Penerapan KUHAP, Sinar Grafika, Jakarta

\section{PERATURAN PERUNDANG- UNDANGAN :}

Undang- Undang Dasar 1945
Kitab Undang-undang Hukum Pidana (KUHP)

UU Nomor 8 tahun 1981 Kitab Undangundang Hukum Acara Pidana

UU Nomor 31 tahun 1999 jo UU Nomor 21 tahun 2001 Tentang Korupsi

UU Nomor 28 tahun 1999 tentang Penyelenggaraan Negara yang Bersih dan Bebas KKN

UU Nomor 26 Tahun 2000 tentang Peradilan HAM Berat

UU Nomor 30 Tahun 2002 tentang Komisi Pemberantasan Korupsi

PP Nomor 2 Tahun 2002 tentang Tata Cara Perlindungan Terhadap Korban dan Saksi dalam Pelanggaran HAM Berat

PP Nomor 71 Tahun 2000 tentang Tata Cara Pelaksanaan Peran Serta Masyarakat dan Pemberian Penghargaan dalam Pemberantasan Tindak Pidana Korupsi

PP Nomor 24 Tahun 2003 tentang Tata Cara Perlindungan Terhadap Saksi, Penyidik, Penuntut Umum, dan Hakim dalam Perkara Tindak Pidana Terorisme. Ghalia Indonesia, Jakarta, 1985.

Joeniarto, R. Demokrasi dan Sistem Pemerintahan Negara, Cetakan Kedua, Bina Aksara, Jakarta, 1982.

Joyep Rewokaho, Prospek Otonomi Daerah di Negara RI, Rajawali Press, Jakarta. 1991.

Krishna, Damarmurti dan Umba Routa, Otonomi Daerah, Perkembangan, Pemikiran dan Pelaksanaannya, PT. Cipta Aditya Bakti. Bandung, 2004.

Miriam Budihardjo, Demokrasi Di Indonesia, Gramedia Pustaka Utama, Jakarta, 1984.

Redaksi Sinar Grafika, Undang-Undang Otonomi Daerah 2004, Penerbit Buku Perundang-undangan. 
Sinar Grafika, Jakarta, Agustus, 2004.

Soehino, Perkembangan Pemerintah Di Daerah, Cetakan Kelima, Liberty, Yogyakarta, 1995.

Soerjono Soekamto, Pengantar Penelitian Hukum, Cetakan Ketiga. UI Press. Jakarta.

Sumindhia, Ninik Widiyanti, Kepala Daerah dan Pengawasannya, Cetakan Pertama, Bina Aksara, Jakarta. 1982.

\section{PERATURAN}

PERUNDANG-

UNDANGAN

Undang-Undang Dasar 1945.

Undang-Undang Nomor 23 Tahun 2014,

Tentang Pemerintahan Daerah 